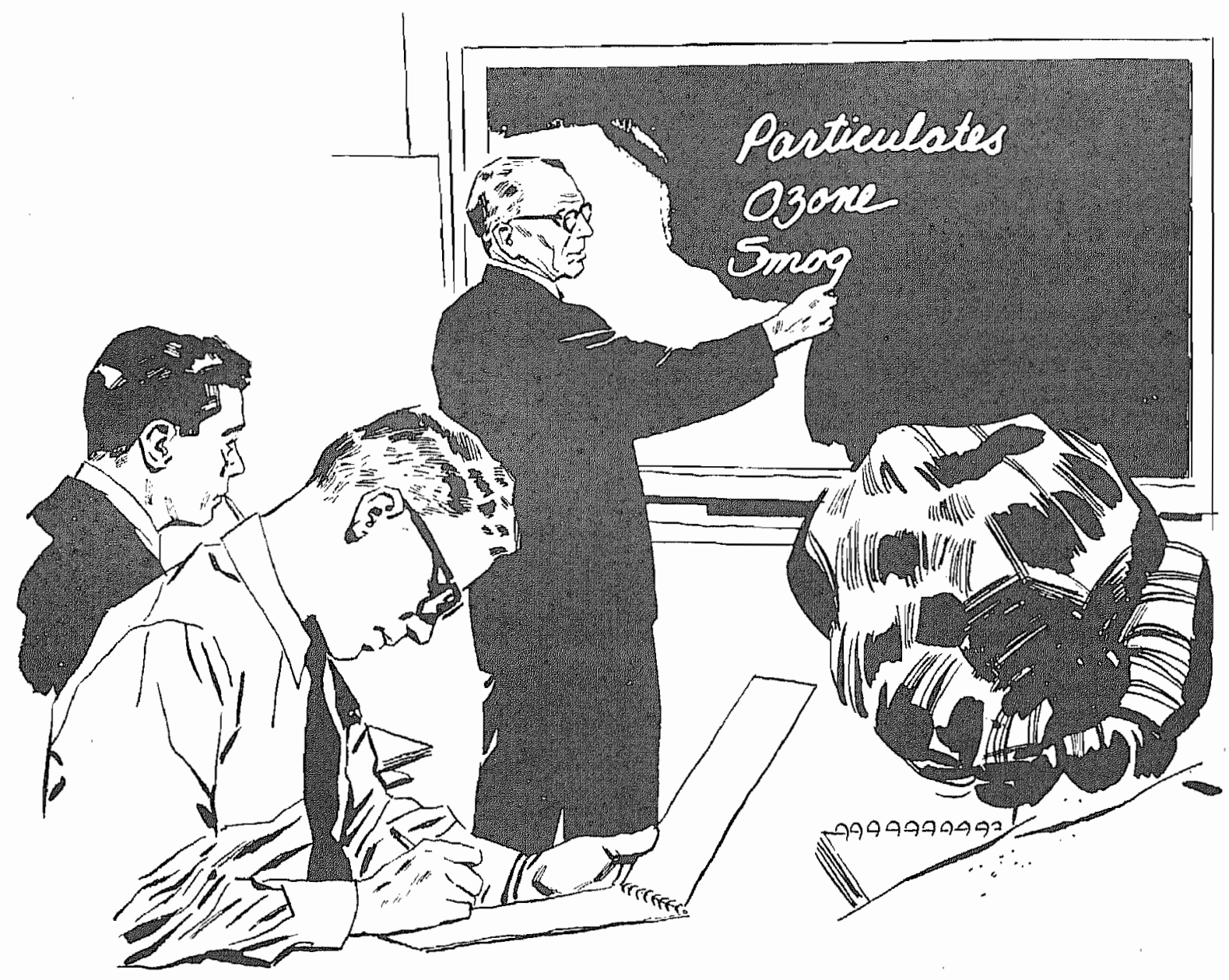

\title{
air pollution control training in
}

\section{colleges and universities:}

\section{a status report for the United States and Canada}

S-11 Education and Training Committee

Survey Report No. 3

Principal Author: Harold M. Cota

The APCA Education and Training Committee surveyed air pollution training at colleges and universities in the United States and Canada in 1975. There were 197 full-time faculty teaching air pollution courses at 75 schools. Graduates from these programs are finding meaningful work in both the public and private sector. Financial support is briefly discussed. 
In 1971, 91 schools indicated they had training efforts in air pollution control. ${ }^{1}$ In an effort to document the changes that have occurred in the last five years, a questionnaire was sent to all schools known to have educational programs in air pollution control. The questionnaire was also published in the March 1975 issue of this Journal. ${ }^{2}$ In addition, listings provided by APCA, the American Society of Engineering Education, and the Environmental Engineering Professors Association were used.

At the present time, 75 colleges and universities across the United States and Canada reported they have air pollution control course work at various levels. This paper summarizes the results of the information collected.

Table I. Faculty tcaching air pollution courses (excluding graduate TA's) ${ }^{\mathrm{a}}$

\begin{tabular}{lrr}
\hline \multicolumn{1}{c}{ Category } & No. & \multicolumn{1}{c}{$\%$} \\
\hline Public health & 25 & 8.83 \\
Biology & 14 & 4.95 \\
Public administration & 2 & 0.71 \\
Chemistry & 25 & 8.83 \\
Environmental engineering & 51 & 18.02 \\
Civil engineering & 30 & 10.60 \\
Chemical engineering & 25 & 8.83 \\
Mechanical enginerring & 28 & 9.89 \\
Other & 83 & 29.33 \\
$\quad$ Total & 283 & \\
\hline
\end{tabular}

a 61 schools reporting.

\section{Air Pollution Control Studies}

A complete list of schools by state is given in Appendix A. Undergraduate, graduate, two year, and some specialized programs are included.

There were 197 full-time faculty teaching air pollution control in the three professional ranks (assistant, associate, and full professor). The background of these and the part-time staff is shown in Table I.

Although space does not permit a detailed description of the academic programs, each school was asked to indicate the number of students they graduated who were qualified to work in some area of air pollution control. These responses are broken down by level in Table IIa.

It was of interest to try to determine the actual number of students placed directly in air pollution related jobs. Many schools did not have this type of information. The results available are given in Table III.

The trend from placement with governmental agencies that predominated several years ago has changed. Graduates are now increasingly being employed by industry and consulting engineers. This is true of those with either undergraduate or graduate degrees. In-

Table Ila. Number of students graduated qualified to work in air pollution. ${ }^{\text {a }}$

\begin{tabular}{rrrrr} 
& A.A. & B.S. & M.S. & Ph.D. \\
\hline Pre-1969 & 0 & 69 & 352 & 57 \\
1969 & 0 & 197 & 214 & 35 \\
1970 & 0 & 356 & 341 &. \\
1971 & 24 & 130 & 163 & 45 \\
1972 & 27 & 135 & 167 & 16 \\
1973 & 85 & 177 & 218 & 33
\end{tabular}

Table IIb. Number of students enrolled in 1974.

\begin{tabular}{lllll}
\hline 1974 & 253 & 425 & 365 & 91 \\
\hline
\end{tabular}

a 43 schools responded to data for $1971-74$;

57 schools responded to data for pre-1971.

dustry is used in the broad sense to mean the private sector which includes those with environmental problems to be solved and those that provide control equipment and services.

The National Research Council (NRC) formed a Committee for the Study of Environmental Manpower to get a more systematic understanding of the present and future manpower needs in the environmental field. ${ }^{3}$ The results are expected early in 1977. The National Institute of Environmental Health Sciences under the auspices of its advisory council is currently updating a study of research needs for Congress. ${ }^{4}$ A study of undergraduate environmental engineering majors at universities in the U.S. is also underway. ${ }^{5}$

\section{Financial Support of the Training Effort}

The level of financial support available at the graduate level in the colleges and universities in 1973 and 1974 is shown in Table IV. This does not include the specialized programs available at Pennsylvania State University and the University of Southern California. In 1974 there were two schools that had enough financial support for one student.

Although there were 104 appointments available in 1974, it is anticipated that currently the support available is less. 25 schools indicated that their primary source was the federal govern-

Table III. Number of students completing an air pollution program and placed in rela ted work. a

\begin{tabular}{lcccc}
\hline & $1971-72$ & $1972-73$ & $1973-74$ & $1974-75$ \\
\hline Control Agency: federal & 27 & 30 & 39 & 1 \\
Control Agency: state & 25 & 42 & 41 & 20 \\
Control Agency: local & 20 & 25 & 34 & 1 \\
Industry (pollution source) & 43 & 37 & 60 & 7 \\
Control Equipment Manufacturing & 1 & 2 & 7 & 4 \\
Industrial Manufacturing & 9 & 1 & 3 & 6 \\
Consulting & 11 & 13 & 27 & 1 \\
University & 6 & 8 & 13 & 6 \\
Other & & & & \\
\hline
\end{tabular}

a36 Schools reporting;

5 Schools reporting for $1974-75$. ment; 19 indicated financial support was available from the state; and 12 schools indicated limited support from industry: The latter was primarily identified with pollution source type firms.

Schools across the country have continued developing programs to train students in air pollution control related specialties. Research facilities have been devoted to seeking answers to the many unanswered questions that arise in air resource management.

In addition to financial support for students, funds are typically required for facilities, faculty development and travel, and part-time employment for the students at all levels.

In 1973 EPA made a policy decision to phase out support of graduate and professional programs by 1976 . Congress provided enough funds in FY 1976 to

Table IV. Financial support available at graduate level programs.

\begin{tabular}{ccc}
\hline $\begin{array}{c}\text { Appointments } \\
\text { per school }\end{array}$ & \multicolumn{2}{c}{ Number of schools } \\
1973 & 2 \\
\hline 1 & & 2 \\
2 & 6 & 2 \\
3 & 3 & 4 \\
4 & & 3 \\
5 & 1 & 1 \\
6 & 3 & 2 \\
7 & 2 & 1 \\
8 & & \\
9 & & 5 \\
10 & 5 &
\end{tabular}


allow about 9 schools limited support in the form of forgivable loans for graduate students. These loans would be forgiven if the students work in control agencies. In FY 1977, it is not clear if Congress will provide EPA with any funds to assist graduate programs.

Research programs and contracts indirectly provide funds for both facilities and student support and some schools will take this route. As the private sector absorbs more of the graduates who are receiving training in air pollution control, it is expected that they will begin directly and indirectly to support the programs.

\section{Conclusions}

It is clear that there has been a nationwide effort over the last few years to train a new generation of air pollution control specialists. The evidence is a clear commitment of faculty and facilities at the schools in Appendix A.

Graduates from these programs are finding meaningful work in local, state and federal agencies and in a wide spectrum of industry. Support for these programs in the future is expected to come from the private sector as funding from state and federal agencies decreases.

Appendix A

\begin{tabular}{|c|c|c|c|c|c|}
\hline State & College or University & Program In & $\begin{array}{l}\text { No. of } \\
\text { Air } \\
\text { Pollution } \\
\text { Courses }\end{array}$ & Degrees & Name \\
\hline Arizona & $\begin{array}{l}\text { Northern Arizona U. } \\
\text { U. of Arizona }\end{array}$ & $\begin{array}{l}\text { PS, EnvS } \\
\text { Atm Sci, CE, } \\
\text { ChE, ME }\end{array}$ & $\begin{array}{l}2 \\
3\end{array}$ & $\begin{array}{l}\text { BS } \\
\text { BS, MS }\end{array}$ & $\begin{array}{l}\text { R. Davis } \\
\text { Walter Fahey }\end{array}$ \\
\hline \multirow[t]{6}{*}{ California } & $\begin{array}{l}\text { Cal. State U. - Humboldt } \\
\text { Cal. State U. - Long Beach } \\
\text { Cal. State U. - Northridge } \\
\text { Cal. State U. - Sacramento } \\
\text { Cal. Poly. State U. - San Luis } \\
\text { Obispo }\end{array}$ & $\begin{array}{l}\text { EnvRE } \\
\text { CE } \\
\text { H Sci } \\
\text { CE } \\
\text { EnvE }\end{array}$ & $\begin{array}{r}6 \\
3 \\
14\end{array}$ & $\begin{array}{l}\text { BS } \\
\text { BS, MS } \\
\text { MS } \\
\text { BS, ME }\end{array}$ & $\begin{array}{l}\text { Al Burrows } \\
\text { V. Phelapati } \\
\text { L. S. Caretto } \\
\text { Ajit Virdee } \\
\text { W. E. Holtz }\end{array}$ \\
\hline & Loyola Marymount U. & $\begin{array}{l}\text { EnvE \& Sci, } \\
\text { WRM }\end{array}$ & 1 & MS, MSE & D. R. Anderson \\
\hline & U. of Calif. - Irvine & Engr & 8 & BS, MS, PhD & J. H. Mulligan \\
\hline & U. of Calif. - Los Angeles & Ap Sci, Engr & 9 & & R. R. O'Neill \\
\hline & U. of Calif. - Riverside & Env Sci & 4 & $A B, B S$ & Garrison Sposito \\
\hline & U. of Southern California & $\begin{array}{l}\text { Env Mang, } \\
\text { Engr }\end{array}$ & 10 & $\mathrm{MS}, \mathrm{PhD}$ & John J. Kirlin \\
\hline Colorado & Colorado State U. & Engr & 7 & BS, MS, PhD & L. V. Baldwin \\
\hline D. of C. & Howard U. & Engr & 7 & $\begin{array}{l}\mathrm{AA}, \mathrm{BS}, \mathrm{ME}, \\
\mathrm{MS}\end{array}$ & Irvin Jones \\
\hline Florida & Florida Tech. U. & Engr & 4 & BS, MS & J. Paul Hartman \\
\hline Georgiat & $\begin{array}{l}\text { U. of Florida - Gainesville } \\
\text { U. of Georgia College of } \\
\text { Agriculture }\end{array}$ & $\begin{array}{l}\text { Env Sci } \\
\text { An \& D Sci }\end{array}$ & $\begin{array}{l}6 \\
2\end{array}$ & BS, MS, Phd & $\begin{array}{l}\text { E. E. Pyatt } \\
\text { Charles H. White }\end{array}$ \\
\hline Hawaii & U. of Hawaii & $\begin{array}{l}\text { A \& S, Engr, } \\
\text { PH }\end{array}$ & 10 & & C. S. Ramage \\
\hline \multirow[t]{3}{*}{ Illinois } & $\begin{array}{l}\text { Governors State U. } \\
\text { Illinois Inst. of Tech. } \\
\text { Northern Illinois U. - DeKalb }\end{array}$ & $\begin{array}{l}\text { Env Sci } \\
\text { EnvE }\end{array}$ & $\begin{array}{l}7 \\
8\end{array}$ & $\begin{array}{l}\mathrm{BS}, \mathrm{MS} \\
\mathrm{MS}, \mathrm{PhD}\end{array}$ & $\begin{array}{l}\text { Ted Andrews } \\
\text { James Patterson } \\
\text { Burley Bechdolt }\end{array}$ \\
\hline & Southern Ill. U. at Carbondalc & Th EnvE & 4 & $\mathrm{BS}, \mathrm{MS}$ & J.W. Chen \\
\hline & $\begin{array}{l}\text { U. of Ill. at Urbania - } \\
\text { Champaign }\end{array}$ & AirR, $\mathrm{CE}$ & 9 & $\mathrm{MS}, \mathrm{PhD}$ & C. P. Siess \\
\hline Indiana & Rosa-Hulman Inst. of Tech & & 1 & & Herbert Bailey \\
\hline Iowa & Iowa State U. & Erth Sci, $\mathrm{ChE}$ & 7 & & George Burnet \\
\hline Kentucky & $\begin{array}{l}\text { U. of Kentucky } \\
\text { Western Kentucky U. }\end{array}$ & $\begin{array}{l}\text { ChE } \\
\text { EnvE T, Env S }\end{array}$ & $\begin{array}{l}5 \\
2\end{array}$ & $\begin{array}{l}\mathrm{MS}, \mathrm{PhD} \\
\mathrm{BS}:\end{array}$ & $\begin{array}{l}\text { R. B. Grieves } \\
\text { Donald R. Rowe }\end{array}$ \\
\hline Louisiama & McNeese State U. & $\mathrm{Sci}$ & 2 & $\mathrm{BS}, \mathrm{MS}$ & V. Monsour \\
\hline Massachusetts & Harvard U. & PH & 4 & $\mathrm{MS}, \mathrm{PhD}$ & D. W. Moeller \\
\hline Maryland & U. of Maryland & Engr, Met & 8 & $\mathrm{BS}, \mathrm{MS}, \mathrm{PhD}$ & H. Landsberg \\
\hline \multirow[t]{2}{*}{ Michigan } & $\begin{array}{l}\text { Ferris St. College } \\
\text { U. of Detroit }\end{array}$ & $\begin{array}{l}\text { Ap IH } \\
\text { Engr }\end{array}$ & $\begin{array}{l}1 \\
2\end{array}$ & $\mathrm{BS}$ & $\begin{array}{l}\text { John R. Fleming } \\
\text { David Camp }\end{array}$ \\
\hline & Wayne State U. & Engr & 4 & $\mathrm{MS}, \mathrm{PhD}$ & Ralph H. Kummler \\
\hline Minnesota & U. of Minnesota & $\mathrm{PH}$ & 6 & $\begin{array}{l}\text { MS, MSPH, } \\
\text { PhD }\end{array}$ & Conrad Straud \\
\hline Missouri & St. Louis U. & Met & 5 & & Ross Heinrich \\
\hline \multirow[t]{3}{*}{ North Carolina } & $\begin{array}{l}\text { Washington Univ. - St. Louis } \\
\text { East Carolina U. - Greenville }\end{array}$ & $\begin{array}{l}\text { ME } \\
\text { Env H }\end{array}$ & $\begin{array}{l}5 \\
1\end{array}$ & & $\begin{array}{l}\text { S.P. Sutera } \\
\text { Trenton G. Davis }\end{array}$ \\
\hline & U. of N. Carolina - Chapel Hill & $\mathrm{PH}$ & 9 & $\begin{array}{l}\text { MSEE, MSPH, } \\
\text { PhD }\end{array}$ & R. F. Christman \\
\hline & $\begin{array}{l}\text { U. of North Carolina - } \\
\text { Charlotte }\end{array}$ & EnvE, Ubn E & & $\mathrm{AA}, \mathrm{BSE}$ & Richard Phelps \\
\hline New Mexico & N.M. Inst. of Mining \& Tech. & EnvE & & BS, MS & L. E. Murr \\
\hline \multirow[t]{2}{*}{ New York } & $\begin{array}{l}\text { Barnard College - Columbia } \\
\text { Univ. }\end{array}$ & Geog & 1 & & Tody Berger Holtz \\
\hline & $\begin{array}{l}\text { Manhattan College } \\
\text { Rensselaer Poly. Inst. }\end{array}$ & $\begin{array}{l}\text { Engr } \\
\text { Ch E, EnvE }\end{array}$ & $\begin{array}{l}2 \\
6\end{array}$ & $\begin{array}{l}\mathrm{BE}, \mathrm{BS}, \mathrm{MS}, \\
\text { PhD }\end{array}$ & $\begin{array}{l}\text { J. Barker } \\
\text { David Hansen }\end{array}$ \\
\hline
\end{tabular}




\section{Acknowledgment}

The author appreciates the assistance of Arthur Stern and Howard Hesketh in developing a list of colleges and universities. Members of the APCA S-11 Committee assisted in various ways with this report. Angela Grenz and Noni Smyth at Cal Poly were most helpful in preparing the report.

\section{References}

1. H. M. Cota, "Air pollution control training in colleges and universities in the United States," J. Air Poll. Control Assoc., 21: 559 (1971); ibid, 22: viii(1972).

2. "1975 APCA colleges and universities survey," J. Air Poll. Control Assoc. 25: 249 (1975).

3. "Clearing the employment picture," $E n$ viron. Sci. Technol. 10: 222 (1976).

4. D. W. Moeller, Harvard University, Per- sonal communication, May 28, 1976

5. J. W. Male, Illinois Institute of 'Technology, Personal communication, January 27,1976 .

Dr. Cota is a professor in the Environmental Engineering Department, California Polytechnic State University, San Luis Obispo, CA 93407.

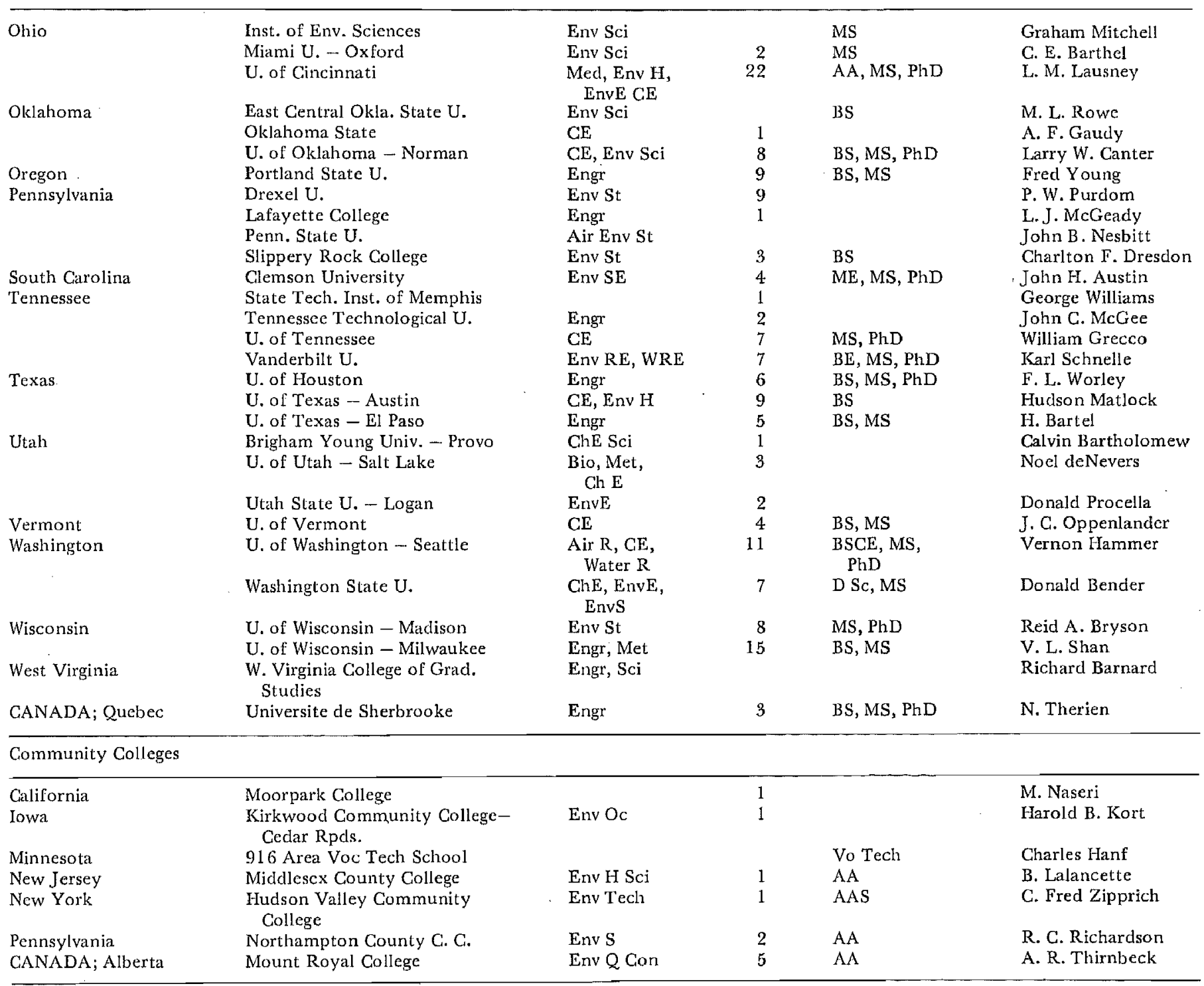

\section{Abbreviations Used}

A \& S:
Air Env St:
Air R:
An \& D Sci:
Ap H:
Ap Sci:
Atm Sci:
Bio:
CE:
Ch E:
Ch E Sci:
D Sc:
Engr:
EnvE:

Arts and Sciences

Air Environmental Studies Air Resources Animal and Dairy Science

Applied Health

Applied Science

Atmospheric Science

Biology

Civil Engineering

Chemical Engineering

Chemical Engineering Science

Doctor of Science

Engineering

Environmental Engineering

EnvE Sci:
Env H:
Env H Sci Tech:
Env Mag:
Env Oc:
Env Q Con:
Env R E:
Env S:
Env Sci:
Env SE:
Env St:

FnvE Sci

Eny H Sci Tech:

Eny Mag

Env Oc:

Env Q Con:

cunv $S \mathrm{E}$

Whost

Environmental Engineering
Sciences
Environmental Health
Environmental Health Science
Environmental Management
Environmental Occupations
Environmental Quality Control
Environmental Resources
Engineering
Environmental Service
Environmental Science
Environmental Systems
Engineering
Environmental Studies

Env Tech:
Erth Sci:
Geog:
H Sci:
ME:
Med:
Met:
PH:
PS:
Sci:
Th E:
Ubn E:
WR:
WRE:
WRM:

Environmental T'echnology
Earth Science
Geography
Health Science
Mechanical Engineering
Medicine
Meteorology
Public Health
Public Service
Science
Thermal Engineering
Urban Engineering
Water Resources
Water Resources Engineering

